Ethan Basch, Mark G. Kris, and Anne Marie Flaherty, Memorial SloanKettering Cancer Center; Barbara Freundlich, Patient Representative, New York; Gary Morrow, University of Rochester Cancer Center, Rochester, NY; Ann Alexis Prestrud and Mark R. Somerfield, American Society of Clinical Oncology, Alexandria, VA; Paul J. Hesketh, Lahey Clinic Medical Center, Burlington, MA; Maurice Chesney, Patient Representative, Saunderstown, RI; Rebecca Anne ClarkSnow, Lawrence Memorial Hospital Oncology Center, Overland Park, KS; Kamakshi V. Rao, University of North Carolina Hospital, Chapel Hill; Gary H. Lyman, Duke University, Durham, NC; Rowena N. Schwartz, The Johns Hopkins Hospital, Baltimore, MD; and Petra C. Feyer, Vivantes Clinic of Radiooncology and Nuclear Medicine, Berlin, Germany.

Submitted December 24, 2010: accepted July 23, 2011; published online ahead of print at www.jco.org on September 26, 2011

Board Approved: June 12, 2011.

Editor's note: This is a brief overview of the American Society of Clinical Oncology (ASCO) Clinical Practice Guideline Update and provides the updated recommendations with brief discussions of the relevant literature for each. The complete guideline, which includes comprehensive discussions of the literature, methodology information, and al cited references, plus a data supplement with evidence tables the Update Committee used to formulate these recommendations are available at www.asco.org/guidelines/antiemetics.

Authors' disclosures of potential conflicts of interest and author contributions are found at the end of this article.

Corresponding author: American Society of Clinical Oncology, 2318 Mill Rd, Suite 800, Alexandria, VA 22314 e-mail: guidelines@asco.org

(C) 2011 by American Society of Clinical Oncology

0732-183X/11/2931-4189/\$20.00

DOI: 10.1200/JCO.2010.34.4614

\title{
Antiemetics: American Society of Clinical Oncology Clinical Practice Guideline Update
}

Ethan Basch, Ann Alexis Prestrud, Paul J. Hesketh, Mark G. Kris, Petra C. Feyer, Mark R. Somerfield, Maurice Chesney, Rebecca Anne Clark-Snow, Anne Marie Flaherty, Barbara Freundlich, Gary Morrow, Kamakshi V. Rao, Rowena N. Schwartz, and Gary H. Lyman

$\begin{array}{llllllll}\text { A } & \text { B } & \text { S } & \text { T } & \text { R } & \text { A } & \text { C } & \text { T }\end{array}$

\section{Purpose}

To update the American Society of Clinical Oncology (ASCO) guideline for antiemetics in oncology.

\section{Methods}

A systematic review of the medical literature was completed to inform this update. MEDLINE, the Cochrane Collaboration Library, and meeting materials from ASCO and the Multinational Association for Supportive Care in Cancer were all searched. Primary outcomes of interest were complete response and rates of any vomiting or nausea.

\section{Results}

Thirty-seven trials met prespecified inclusion and exclusion criteria for this systematic review. Two systematic reviews from the Cochrane Collaboration were identified; one surveyed the pediatric literature. The other compared the relative efficacy of the 5-hydroxytryptamine-3 $\left(5-\mathrm{HT}_{3}\right)$ receptor antagonists.

\section{Recommendations}

Combined anthracycline and cyclophosphamide regimens were reclassified as highly emetic. Patients who receive this combination or any highly emetic agents should receive a $5-\mathrm{HT}_{3}$ receptor antagonist, dexamethasone, and a neurokinin $1\left(\mathrm{NK}_{1}\right)$ receptor antagonist. A large trial validated the equivalency of fosaprepitant, a single-day intravenous formulation, with aprepitant; either therapy is appropriate. Preferential use of palonosetron is recommended for moderate emetic risk regimens, combined with dexamethasone. For low-risk agents, patients can be offered dexamethasone before the first dose of chemotherapy. Patients undergoing high emetic risk radiation therapy should receive a $5-\mathrm{HT}_{3}$ receptor antagonist before each fraction and for 24 hours after treatment and may receive a 5-day course of dexamethasone during fractions 1 to 5 . The Update Committee noted the importance of continued symptom monitoring throughout therapy. Clinicians underestimate the incidence of nausea, which is not as well controlled as emesis.

\section{J Clin Oncol 29:4189-4198. C 2011 by American Society of Clinical Oncology}

\section{INTRODUCTION}

The first American Society of Clinical Oncology (ASCO) guideline for the use of antiemetics was published in $1999^{1}$ and updated once in $2006 .^{2}$ This guideline provides clinicians with recommendations to prevent vomiting and nausea among patients undergoing antineoplastic therapy (chemotherapyinduced nausea and vomiting [CINV]) and/or radiation therapy (radiation-induced nausea and vomiting [RINV]) based on evidence from randomized clinical trials.

\section{METHODS}

An Update Committee (Appendix Table A1, online only) met twice to review data published since 2006 and update recommendations as warranted.

\section{Literature Review}

Literature search strategy. A systematic review on the effectiveness of newer antiemetics (aprepitant and the 5-hydroxytryptamine-3 $\left[5-\mathrm{HT}_{3}\right]$ receptor antagonists), funded by the Agency for Healthcare Research and Quality, was initially reviewed for relevant publications. Two MEDLINE searches (search strategy available in the Data Supplement, http://www.asco.org/guidelines/antiemetics) were completed to identify additional randomized controlled trials; a search of the Cochrane Collaboration Library was also conducted. Meeting materials from the ASCO and Multinational Association of Supportive Care in Cancer annual meetings available since the 2006 update were additionally culled. Only full presentations or posters were eligible; material available only in abstract form was not considered.

Inclusion and exclusion criteria. Systematic reviews and reports from randomized controlled trials eligible for inclusion met the following criteria: the intervention was for the treatment of nausea or vomiting secondary 
to cancer therapy; nausea and/or vomiting outcomes were reported; patients were observed for a minimum of 5 days (120 hours) after the intervention; and each trial arm included a minimum of 25 randomly assigned patients. Evidence tables are provided in the Data Supplement.

The guideline was reviewed and approved by the ASCO Clinical Practice Guidelines Committee and the Board of Directors and underwent review and approval for publication in the Journal of Clinical Oncology.

\section{THE BOTTOM LINE}

\section{American Society of Clinical Oncology Clinical Practice Guideline Update on Antiemetics}

\section{Intervention}

- Antiemetics for patients receiving cancer therapy.

\section{Target Audience}

- Medical Oncologists, Radiation Oncologists, Oncology Nurses.

\section{Key Recommendations}

- Patients who receive highly emetic chemotherapy regimens should receive the three-drug combination of a neurokinin $1\left(\mathrm{NK}_{1}\right)$ antagonist, 5-hydroxytryptamine-3 $\left(5-\mathrm{HT}_{3}\right)$ antagonist, and dexamethasone.

- The preferred $5-\mathrm{HT}_{3}$ antagonist for patients who receive moderate emetic chemotherapy regimens is palonosetron; antiemetic treatment includes that agent combined with a corticosteroid.

- Antiemetic treatment for patients who receive combination chemotherapy should be determined according to the agent with the greatest degree of emetic risk.

- Both dexamethasone and a 5- $\mathrm{HT}_{3}$ antagonist are recommended for patients undergoing high-dose chemotherapy.

- Pediatric patients receiving either high or moderate emetic risk chemotherapy should be treated with a $5-\mathrm{HT}_{3}$ antagonist and corticosteroids; higher weight-based dosing may be required.

- For those treated with high emetic risk radiation therapy, a $5-\mathrm{HT}_{3}$ antagonist before each fraction and a 5-day course of dexamethasone are recommended.

- A $5-\mathrm{HT}_{3}$ antagonist before each fraction is also recommended before moderate-risk radiation; a 5-day course of dexamethasone is optional.

- For patients who receive combination chemoradiotherapy, antiemetic therapy is dictated by the emetogenicity of chemotherapy, unless the emetic risk of radiation therapy is higher.

\section{Methods}

- A systematic review of the literature published since the last update of the guideline.

The data supplement, including evidence tables and clinical tools and resources, can be found at www.asco.org/

guidelines/antiemetics.

\section{Guideline Policy}

This Executive Summary for physicians is an abridged summary of an ASCO practice guideline. The practice guideline and this summary are not intended to substitute for the independent professional judgment of the treating physician. Practice guidelines do not account for individual variation among patients and may not reflect the most recent evidence. This summary does not recommend any particular product or course of medical treatment. Use of the practice guideline and this summary is voluntary. The full practice guideline and additional information are available at http://www.asco.org/ guidelines/antiemetics.

\section{Guideline and Conflict of Interest}

The Update Committee was assembled in accordance with ASCO's Conflict of Interest Management Procedures for Clinical Practice Guidelines ("Procedures," summarized at http://www.asco.org/guidelinescoi). Members of the Update Committee completed ASCO's disclosure form, which requires disclosure of financial and other interests that are relevant to the subject matter of the guideline, including relationships with commercial entities that are reasonably likely to experience direct regulatory or commercial impact as the result of promulgation of the guideline. Categories for disclosure include employment relationships, consulting arrangements, stock ownership, honoraria, research funding, and expert testimony. In accordance with the Procedures, the majority of the members of the Update Committee did not disclose any such relationships.

\section{RESULTS}

The literature search from 2006 to December 2009 yielded a total of 271 unique citations from MEDLINE and 48 from meetings (QUOROM Diagram available in Data Supplement). Thirty-six reports met inclusion criteria and were selected for data extraction; 11 $(30.6 \%)$ were reports from meetings.

\section{GUIDELINE RECOMMENDATIONS}

\section{CHEMOTHERAPY-INDUCED NAUSEA AND VOMITING}

Updated recommendations are listed in Table 1. Table 2 lists intravenous agents organized by emetic risk. Dosing schedules for each risk class are listed in Table 3.

\section{Clinical Question 1}

What is the optimal treatment to prevent nausea and vomiting from highly emetogenic antineoplastic agents?

Recommendation 1. The three-drug combination of a neurokinin $1\left(\mathrm{NK}_{1}\right)$ receptor antagonist (days 1 through 3 for aprepitant; day 1 only for fosaprepitant), a $5-\mathrm{HT}_{3}$ receptor antagonist (day 1 only), and dexamethasone (days 1 through 3 or 1 through 4 ) is recommended for patients receiving highly emetogenic chemotherapy. The Update Committee also recommended reclassification of the combined anthracycline and cyclophosphamide (AC) regimen as highly emetogenic.

Literature update and analysis 1. Five new trials were identified. ${ }^{3-7}$ The study by Hoshi et $\mathrm{al}^{5}$ provided additional data (Data Supplement) that support use of aprepitant for patients undergoing high-risk chemotherapy.

An equivalency study compared fosaprepitant, a 1-day intravenous formulation of aprepitant, with oral aprepitant. ${ }^{3,8}$ Findings demonstrate equivalence between the agents for complete response and both emesis and nausea control. Fosaprepitant was endorsed by the Update Committee as an acceptable $\mathrm{NK}_{1}$ receptor antagonist. 
Table 1. Summary of Recommendations

\begin{tabular}{|c|c|c|}
\hline Clinical Situation & 2006 Recommendation & 2011 Reccomendation \\
\hline
\end{tabular}

Chemotherapy-induced nausea

and vomiting

Highly emetogenic agents

Moderately emetogenic agents

Low emetogenic agents

Minimally emetogenic agents

Combination chemotherapy

Adjunctive drugs

Complementary therapy

Pediatric patients

High-dose chemotherapy with stem-cell or bone marrow transplantation

Multiday chemotherapy

The three-drug combination of a $5-\mathrm{HT}_{3}$ receptor antagonist, dexamethasone, and aprepitant is recommended before chemotherapy. In all patients receiving cisplatin and all other agents of high emetic risk, the two-drug combination of dexamethasone and aprepitant is recommended. The Update Committee no longer recommends the combination of a $5-\mathrm{HT}_{3}$ serotonin receptor antagonist and dexamethasone on days 2 and 3.

The three-drug combination of a $5-\mathrm{HT}_{3}$ receptor antagonist, dexamethasone, and aprepitant is recommended for patients receiving $\mathrm{AC}$. For patients receiving chemotherapy of moderate emetic risk other than $\mathrm{AC}$, we recommend the two-drug combination of a $5-\mathrm{HT}_{3}$ receptor antagonist and dexamethasone. In patients receiving $\mathrm{AC}$, aprepitant as a single agent is recommended on days 2 and 3 . For all other chemotherapies of moderate emetic risk, singleagent dexamethasone or a $5-\mathrm{HT}_{3}$ receptor antagonist is suggested for the prevention of emesis on days 2 and 3 .

Dexamethasone $8 \mathrm{mg}$ is suggested. No routine preventive use of antiemetics for delayed emesis is suggested.

No change from the original guideline. No antiemetic should be administered routinely before or after chemotherapy.

No change from the original guideline. Patients should be administered antiemetics appropriate for the chemotherapeutic agent of greatest emetic risk.

Lorazepam and diphenhydramine are useful adjuncts to antiemetic drugs but are not recommended as single agents.

New question for 2011 update.

The combination of a $5-\mathrm{HT}_{3}$ antagonist plus a corticosteroid is suggested before chemotherapy in children receiving chemotherapy of high or moderate emetic risk. Because of variation of pharmacokinetic parameters in children, higher weight-based doses of $5-\mathrm{HT}_{3}$ antagonists than those used in adults may be required for antiemetic protection.

No change from original guideline. A $5-\mathrm{HT}_{3}$ receptor antagonist antiemetic combined with dexamethasone is suggested. Aprepitant should be considered, although evidence to support its use specifically in these patients is lacking.

No change from the original guideline. It is suggested that antiemetics appropriate for the risk class of the chemotherapy, as outlined earlier, be administered for each day of the chemotherapy and for 2 days after, if appropriate.

Emesis or nausea despite optimal prophylaxis

Anticipatory nausea and vomiting active antiemetic regimens appropriate for the chemothera-
No change from original guideline. The Update Committee suggests that clinicians conduct a careful re-evaluation of emetic risk, disease status, concurrent illnesses, and medications; ascertain that the best regimen is being administered for the emetic risk; consider adding lorazepam or alprazolam to the regimen; and consider substituting a high-dose intravenous metoclopramide for the $5-\mathrm{HT}_{3}$ antagonist or adding a dopamine antagonist to the regimen.

No change since the original guideline. Use of the most py being administered to prevent acute or delayed emesis is suggested. Such regimens may be used with the initial chemotherapy, rather than assessing the patient's emetic response with less effective treatment. If anticipatory emesis occurs, behavioral therapy with systematic desensitization is effective and suggested.
The three-drug combination of an $\mathrm{NK}_{1}$ receptor antagonist (days 1-3 for aprepitant; day 1 only for fosaprepitant), a 5 $\mathrm{HT}_{3}$ receptor antagonist (day 1 only), and dexamethasone (days 1-3 or 1-4) is recommended for patients receiving highly emetogenic chemotherapy. This recommendation is unchanged since the 2006 update, but reworded for clarification. The Update Committee also recommended reclassification of the combined $\mathrm{AC}$ regimen as highly emetogenic.

The two-drug combination of palonosetron (day 1 only) and dexamethasone (days 1-3) is recommended for patients receiving moderately emetogenic chemotherapy. If palonosetron is not available, clinicians may substitute a first-generation $5-\mathrm{HT}_{3}$ serotonin receptor antagonist, preferably granisetron or ondansetron. Limited evidence also supports adding aprepitant to the combination. Should clinicians opt to add aprepitant in patients receiving moderate-risk chemotherapy, any one of the $5-\mathrm{HT}_{3}$ antagonists is appropriate.

A single 8-mg dose of dexamethasone before chemotherapy is suggested. No change since 2006.

No antiemetic should be administered routinely before or after chemotherapy. No change from the original guideline.

Patients should be administered antiemetics appropriate for the component chemotherapeutic (antineoplastic) agent of greatest emetic risk. No change from the original guideline. AC combinations are now classified as highly emetogenic.

Lorazepam or diphenhydramine are useful adjuncts to antiemetic drugs but are not recommended as single-agent antiemetics. No change since 2006.

No published randomized controlled trial data that met inclusion criteria are currently available to support a recommendation about such therapies.

The combination of a $5-\mathrm{HT}_{3}$ antagonist plus a corticosteroid is suggested before chemotherapy in children receiving chemotherapy of high or moderate emetic risk. Because of variation of pharmacokinetic parameters in children, higher weight-based doses of $5-\mathrm{HT}_{3}$ antagonists than those used in adults may be required for antiemetic protection. No change since 2006.

A $5-\mathrm{HT}_{3}$ receptor antagonist combined with dexamethasone is suggested. Aprepitant should be considered, although evidence to support its use is limited.

It is suggested that antiemetics appropriate for the emetogenic risk class of the chemotherapy be administered for each day of the chemotherapy and for 2 days after, if appropriate. No change from the original guideline. The Update Committee suggests, based on limited data, that patients receiving 5day cisplatin regimens be treated with a $5-\mathrm{HT}_{3}$ antagonist in combination with dexamethasone and aprepitant.

Clinicians should re-evaluate emetic risk, disease status, concurrent illnesses, and medications; ascertain that the best regimen is being administered for the emetic risk; consider adding lorazepam or alprazolam to the regimen; and consider adding olanzapine to the regimen or substituting high-dose intravenous metoclopramide for the 5- $\mathrm{HT}_{3}$ antagonist or adding a dopamine antagonist to the regimen.

Use of the most active antiemetic regimens appropriate for the chemotherapy being administered to prevent acute or delayed emesis is suggested. Such regimens should be used with initial chemotherapy, rather than assessing the patient's emetic response with less effective treatment. If anticipatory emesis occurs, behavioral therapy with systematic desensitization is effective and suggested. No change since the original guideline. 
Table 1. Summary of Recommendations (continued)

\begin{tabular}{|c|c|c|}
\hline \multicolumn{3}{|l|}{$\begin{array}{l}\text { Radiation-induced nausea } \\
\text { and vomiting }\end{array}$} \\
\hline High risk & $\begin{array}{l}\text { No change from original guideline. The Update Committee } \\
\text { suggests administration a } 5-\mathrm{HT}_{3} \text { antagonist with or without } \\
\text { a corticosteroid before each fraction and for at least } 24 \\
\text { hours after. There is no change from the original guideline. }\end{array}$ & $\begin{array}{l}\text { On the basis of extrapolation from indirect evidence, the } \\
\text { Update Committee recommends that all patients should } \\
\text { receive a } 5-\mathrm{HT}_{3} \text { antagonist before each fraction and for at } \\
\text { least } 24 \text { hours after completion of radiotherapy. Patients } \\
\text { should also receive a } 5 \text {-day course of dexamethasone } \\
\text { during fractions 1-5. }\end{array}$ \\
\hline Moderate risk & $\begin{array}{l}\text { The Update Committee recommends a } 5-\mathrm{HT}_{3} \text { antagonist } \\
\text { before each fraction. }\end{array}$ & $\begin{array}{l}\text { The Update Committee recommends that patients receive a } \\
5-\mathrm{HT}_{3} \text { antagonist before each fraction for the entire course } \\
\text { of radiotherapy. Patients may be offered a short course of } \\
\text { dexamethasone during fractions } 1-5 \text {. }\end{array}$ \\
\hline Low risk & $\begin{array}{l}\text { No change from original guideline. The Update Committee } \\
\text { recommends a } 5-\mathrm{HT}_{3} \text { antagonist before each fraction. }\end{array}$ & $\begin{array}{l}\text { The Update Committee recommends a } 5-\mathrm{HT}_{3} \text { antagonist alone } \\
\text { as either prophylaxis or rescue. For patients who experience } \\
\text { radiation-induced nausea and vomiting while receiving } \\
\text { rescue therapy only, prophylactic treatment should continue } \\
\text { until radiotherapy is complete. }\end{array}$ \\
\hline $\begin{array}{l}\text { Combined chemotherapy } \\
\text { and radiation therapy }\end{array}$ & $\begin{array}{l}\text { Patients should receive antiemetic prophylaxis according to } \\
\text { the emetogenicity of chemotherapy, unless the emetic risk } \\
\text { with the planned radiotherapy is higher. No change from } \\
\text { the original guideline. }\end{array}$ & $\begin{array}{l}\text { Patients should receive antiemetic prophylaxis according to the } \\
\text { emetogenicity of chemotherapy, unless the emetic risk with } \\
\text { the planned radiotherapy is higher. No change from the } \\
\text { original guideline. }\end{array}$ \\
\hline
\end{tabular}

The pilot study by Herrington et $\mathrm{al}^{4}$ compared two dosing schedules of aprepitant ( 1 day $v 3$ days). No differences in rates of complete response and emetic episodes for the overall study period were reported. Studies to validate the noninferiority of single-day oral aprepitant are necessary to establish equivalence.

A pilot study compared olanzapine with aprepitant. ${ }^{6}$ Patients randomly assigned to olanzapine experienced similar complete response rates as patients who received aprepitant. Olanzapine was superior for nausea control during the overall study period $(P<.01)$. Additional trials are necessary to define the role of olanzapine in this setting.

The AC combination was reclassified based on the high emetic potential of the combined agents. Data from placebo-controlled studies indicate that this combination causes vomiting in $85 \%$ of patients not receiving antiemetic prophylaxis. ${ }^{9}$ This borders on the cutoff defined for highly emetogenic agents. ${ }^{9}$

\section{Clinical Question 2}

What is the optimal treatment to prevent nausea and vomiting from moderately emetogenic antineoplastic agents?

Recommendation 2. The two-drug combination of palonosetron (day 1 only) and dexamethasone (days 1 through 3 ) is recommended for patients receiving moderately emetogenic chemotherapy. If palonosetron is not available, clinicians may substitute a first-generation $5-\mathrm{HT}_{3}$ receptor antagonist, preferably granisetron or ondansetron.

Limited evidence also supports adding aprepitant to the combination. Should clinicians opt to add aprepitant in patients receiving moderate-risk chemotherapy, any one of the $5-\mathrm{HT}_{3}$ antagonists is appropriate.

Literature update and analysis $2 a: 5-H_{3}$ receptor antagonist equivalency. The Update Committee evaluated therapeutic equivalence of the $5-\mathrm{HT}_{3}$ receptor antagonists (ondansetron, granisetron, dolasetron, palonosetron, ramosetron, and tropisetron). A Cochrane Re- view of $5-\mathrm{HT}_{3}$ antagonists used to prevent $\mathrm{CINV}$ was identified. ${ }^{10}$ Most trials compared ondansetron and granisetron. Few trials including dolasetron and tropisetron were identified, and only one study with palonosetron was included, ${ }^{11}$ which is described in this section. No studies on ramosetron were included. Findings from the review suggest equivalency between ondansetron and granisetron, supported by a meta-analysis (Data Supplement). Another meta-analysis from Jordan et $\mathrm{al}^{12}$ assessed only first-generation $5-\mathrm{HT}_{3}$ receptor antagonists. This study also indicates equivalency of granisetron and ondansetron and superiority of granisetron compared with tropisetron.

A study comparing ramosetron and granisetron was identified. ${ }^{13}$ Findings indicate similar rates of complete response during the first 24 hours after chemotherapy. Research describing the efficacy of ramosetron during the 7-day period after chemotherapy is not available.

Three studies compared palonosetron with first-generation 5- $\mathrm{HT}_{3}$ antagonists. ${ }^{1,14,15}$ Findings from two larger studies ${ }^{11,16}$ suggested that palonosetron provides superior protection against both nausea and vomiting, particularly during the period from 24 to 120 hours after chemotherapy. However, the third study yielded nonsignificant differences, which might be explained by the fact that it was designed as a noninferiority trial. ${ }^{15}$

These studies were conducted in combined emetic risk populations, but not a non-AC moderately emetogenic population, and compared palonosetron with a first-generation $5-\mathrm{HT}_{3}$ receptor antagonist in which dexamethasone has also been included. The preference for palonosetron is an extrapolation from the Saito et $\mathrm{al}^{11}$ data; when an $\mathrm{NK}_{1}$ receptor antagonist is not used in the setting of cisplatin and AC chemotherapy, the combination of palonosetron and dexamethasone is superior to granisetron and dexamethasone. By inference, with non-AC moderately emetogenic chemotherapy, palonosetron and dexamethasone are also likely to be superior to a first-generation $5-\mathrm{HT}_{3}$ receptor antagonist and dexamethasone. 


\begin{tabular}{|c|c|}
\hline Emetic Risk & Agent \\
\hline High & $\begin{array}{l}\text { Carmustine } \\
\text { Cisplatin } \\
\text { Cyclophosphamide } \geq 1,500 \mathrm{mg} / \mathrm{m}^{2} \\
\text { Dacarbazine } \\
\text { Dactinomycin } \\
\text { Mechlorethamine } \\
\text { Streptozotocin }\end{array}$ \\
\hline Moderate & $\begin{array}{l}\text { Azacitidine } \\
\text { Alemtuzumab } \\
\text { Bendamustine } \\
\text { Carboplatin } \\
\text { Clofarabine } \\
\text { Cyclophosphamide }<1,500 \mathrm{mg} / \mathrm{m}^{2} \\
\text { Cytarabine }>1,000 \mathrm{mg} / \mathrm{m}^{2} \\
\text { Daunorubicin* } \\
\text { Doxorubicin* } \\
\text { Epirubicin* } \\
\text { Idarubicin* } \\
\text { Ifosfamide } \\
\text { Irinotecan } \\
\text { Oxaliplatin }\end{array}$ \\
\hline Low & $\begin{array}{l}\text { Fluorouracil } \\
\text { Bortezomib } \\
\text { Cabazitaxel } \\
\text { Catumaxomab } \\
\text { Cytarabine } \leq 1,000 \mathrm{mg} / \mathrm{m}^{2} \\
\text { Docetaxel } \\
\text { Doxorubicin HCL liposome injection } \\
\text { Etoposide } \\
\text { Gemcitabine } \\
\text { Ixabepilone } \\
\text { Methotrexate } \\
\text { Mitomycin } \\
\text { Mitoxantrone } \\
\text { Paclitaxel } \\
\text { Panitumumab } \\
\text { Pemetrexed } \\
\text { Temsirolimus } \\
\text { Topotecan } \\
\text { Trastuzumab }\end{array}$ \\
\hline Minimal & $\begin{array}{l}\text { 2-Chlorodeoxyadenosine } \\
\text { Bevacizumab } \\
\text { Bleomycin } \\
\text { Busulfan } \\
\text { Cetuximab } \\
\text { Fludarabine } \\
\text { Pralatrexate } \\
\text { Rituximab } \\
\text { Vinblastine } \\
\text { Vincristine } \\
\text { Vinorelbine }\end{array}$ \\
\hline \multicolumn{2}{|c|}{$\begin{array}{l}\text { NOTE. This list of agents is not exhaustive. } \\
\text { Abbreviation: HCL, hydrochloride. } \\
\text { "These anthracyclines, when combined with cyclophosphamide, are now } \\
\text { designated as high emetic risk. }\end{array}$} \\
\hline
\end{tabular}

Literature update and analysis $2 b: N K_{1}$ receptor antagonist for moderately emetogenic chemotherapy. One trial evaluated the utility of aprepitant in patients undergoing moderately emetogenic chemotherapy. ${ }^{17}$ Improved CINV protection with aprepitant was noted. An advantage of using aprepitant with moderate-risk agents is abbreviated dexamethasone dosing.

\begin{tabular}{|c|c|c|}
\hline Risk Category & $\begin{array}{l}\text { Dosing on Day of } \\
\text { Chemotherapy }\end{array}$ & $\begin{array}{c}\text { Dosing on } \\
\text { Subsequent Days }\end{array}$ \\
\hline \multicolumn{3}{|l|}{ High emetic risk ${ }^{*}$} \\
\hline \multicolumn{3}{|l|}{$\mathrm{NK}_{1}$ antagonist } \\
\hline Aprepitant & $125 \mathrm{mg}$ oral & $\begin{array}{l}80 \mathrm{mg} \text { oral; days } 2 \\
\text { and } 3\end{array}$ \\
\hline Fosaprepitant & $150 \mathrm{mg} \mathrm{IV}$ & \\
\hline \multicolumn{3}{|l|}{$5-\mathrm{HT}_{3}$ antagonist } \\
\hline Granisetron & $\begin{array}{l}2 \mathrm{mg} \text { oral; } 1 \mathrm{mg} \text { or } 0.01 \\
\mathrm{mg} / \mathrm{kg} \text { IV }\end{array}$ & \\
\hline Ondansetron & $\begin{array}{c}8 \mathrm{mg} \text { oral twice daily; } 8 \\
\mathrm{mg} \text { or } 0.15 \mathrm{mg} / \mathrm{kg} \text { IV }\end{array}$ & \\
\hline Palonosetron & $0.50 \mathrm{mg}$ oral; $0.25 \mathrm{mg} \mathrm{IV}$ & \\
\hline Dolasetron & $100 \mathrm{mg}$ oral ONLY & \\
\hline Tropisetron & $5 \mathrm{mg}$ oral; $5 \mathrm{mg} \mathrm{IV}$ & \\
\hline Ramosetron & $0.3 \mathrm{mg}$ IV & \\
\hline \multicolumn{3}{|l|}{$\begin{array}{l}\text { Corticosteroid if } \\
\text { aprepitant is } \\
\text { usedt }\end{array}$} \\
\hline Dexamethasone & $12 \mathrm{mg}$ oral or IV & $\begin{array}{l}8 \mathrm{mg} \text { oral or IV; days } 2 \\
\text { and } 3 \text { or days } 2-4\end{array}$ \\
\hline \multicolumn{3}{|l|}{$\begin{array}{l}\text { Corticosteroid if } \\
\text { fosaprepitant is } \\
\text { usedt }\end{array}$} \\
\hline Dexamethasone & $12 \mathrm{mg}$ oral or IV & $\begin{array}{l}8 \mathrm{mg} \text { oral or IV day } 2 ; \\
8 \mathrm{mg} \text { oral or IV } \\
\text { twice per day on } \\
\text { days } 3 \text { and } 4\end{array}$ \\
\hline \multicolumn{3}{|l|}{ Moderate emetic risk‡ } \\
\hline \multicolumn{3}{|l|}{ 5- $\mathrm{HT}_{3}$ antagonist } \\
\hline Palonosetron & $0.50 \mathrm{mg}$ oral; $0.25 \mathrm{mg} \mathrm{IV}$ & \\
\hline \multicolumn{3}{|l|}{ Corticosteroid } \\
\hline Dexamethasone & $8 \mathrm{mg}$ oral or IV & $8 \mathrm{mg}$; days 2 and 3 \\
\hline \multicolumn{3}{|l|}{ Low emetic risk } \\
\hline \multicolumn{3}{|l|}{ Corticosteroid } \\
\hline Dexamethasone & $8 \mathrm{mg}$ oral or IV & \\
\hline \multicolumn{3}{|c|}{$\begin{array}{l}\text { NOTE. For patients receiving multiday chemotherapy, clinicians must first } \\
\text { determine the emetic risk of the agent(s) included in the regimen. Patients } \\
\text { should receive the agent of the highest therapeutic index daily during } \\
\text { chemotherapy and for } 2 \text { days thereafter. Patients can also be offered the } \\
\text { granisetron transdermal patch that delivers therapy over multiple days rather } \\
\text { than taking a serotonin antagonist daily. } \\
\text { Abbreviations: } 5-\mathrm{HT}_{3}, 5 \text {-hydroxytryptamine-3; } \mathrm{IV} \text {, intravenous; } \mathrm{NK}_{1} \text {, neurokinin } 1 \text {. } \\
\text { "Includes combination of an anthracycline and cyclophosphamide. } \\
\text { †The dexamethasone dose is for patients who are receiving the recom- } \\
\text { mended three-drug regimen for highly emetic chemotherapy. If patients do } \\
\text { not receive an } \mathrm{NK}_{1} \text { antagonist, the dexamethasone dose should be adjusted to } \\
20 \mathrm{mg} \text { on day } 1 \text { and } 16 \mathrm{mg} \text { on days } 2 \text { to } 4 \text {. } \\
\neq \text { Clinicians who choose to use an NK } \mathrm{NK}_{1} \text { antagonist should follow high emetic } \\
\text { risk chemotherapy dosing. Importantly, corticosteroid is only given on day } 1 \text {; } \\
\text { dexamethasone dose is } 12 \mathrm{mg} \text {. }\end{array}$} \\
\hline
\end{tabular}

Literature update and analysis 2c: Dexamethasone dosing. Two trials $^{16,18}$ evaluated dexamethasone dosing, comparing 1- and 3-day dexamethasone dosing combined with palonosetron. Findings from these trials suggest similar outcomes with the two regimens. Additional trials that validate these findings may warrant a change to the current recommendation.

\section{Clinical Question 3}

What is the optimal treatment to prevent nausea and vomiting from low emetogenic antineoplastic agents?

Recommendation 3. A single 8-mg dose of dexamethasone before chemotherapy is suggested.

Literature update and analysis 3. No new evidence was identified. 


\section{Clinical Question 4}

What is the optimal treatment to prevent nausea and vomiting from minimally emetogenic antineoplastic agents?

Recommendation 4. No antiemetic should be administered routinely before or after chemotherapy.

Literature update and analysis 4 . No new evidence was identified.

\section{Clinical Question 5}

What is the optimal treatment to prevent nausea and vomiting from combination chemotherapy?

Recommendation 5. Patients should be administered antiemetics appropriate for the component chemotherapeutic (antineoplastic) agent of greatest emetic risk. AC combinations are now classified as highly emetogenic.

Literature update and analysis 5. No new evidence was identified.

\section{Clinical Question 6}

What is the role of adjunctive drugs for nausea and vomiting induced by cancer treatments?

Recommendation 6. Lorazepam and diphenhydramine are useful adjuncts to antiemetic drugs but are not recommended as singleagent antiemetics.

Literature update and analysis 6. One new trial evaluated the impact of including olanzapine in antiemetic regimens. ${ }^{19}$ Benefits of olanzapine were most evident during the days after chemotherapy.

\section{Clinical Question 7}

What is the role of complementary and alternative medicine therapies to prevent or control nausea and vomiting induced by chemotherapy?

Recommendation 7 . No published randomized controlled trial data that met inclusion criteria are currently available to support a recommendation about such therapies.

Literature update and analysis 7. A phase III trial of ginger was presented at an ASCO meeting in 2009. ${ }^{20}$ No significant differences in the prevalence of vomiting and nausea between patients who received ginger and placebo were reported.

A Cochrane Systematic Review of acupuncture-point stimulation for CINV was published. ${ }^{21}$ However, this effort did not meet prespecified inclusion and exclusion criteria for this systematic review.

\section{SPECIAL POPULATIONS}

\section{Clinical Question 8}

What is the optimal treatment to prevent nausea and vomiting associated with cancer therapy for pediatric patients?

Recommendation 8. The combination of a $5-\mathrm{HT}_{3}$ antagonist plus a corticosteroid is suggested before chemotherapy in children receiving chemotherapy of high or moderate emetic risk. Because of the variation of pharmacokinetic parameters in children, higher weight-based doses of $5-\mathrm{HT}_{3}$ antagonists than those used in adults may be required for antiemetic protection. There is no change in this recommendation from 2006.

Literature update and analysis 8 . A systematic review of available therapies for CINV in children was published by the Cochrane Collaboration. ${ }^{22} \mathrm{Few}$ trials identified had similarities in intervention characteristics, so the review was primarily qualitative. A pooled analysis indicates that the addition of dexamethasone to the newer $5-\mathrm{HT}_{3}$ antagonists provides benefits in the high emetic risk setting.
Two trials were also identified. One assessed the use of aprepitant in this population. ${ }^{23}$ The second evaluated the efficacy and safety of palonosetron in pediatric patients. ${ }^{24}$

\section{Clinical Question 9}

What is the optimal treatment to prevent nausea and vomiting in patients who are undergoing high-dose chemotherapy with stem-cell or bone marrow transplantation?

Recommendation 9. A 5- $\mathrm{HT}_{3}$ receptor antagonist combined with dexamethasone is recommended. Aprepitant should be considered, although evidence to support its use is limited.

Literature update and analysis 9. Two new studies were identified. ${ }^{25,26}$ One report detailed superior emetic control with palonosetron. Data suggest that 2 days of palonosetron therapy will decrease the likelihood of CINV. The other trial evaluated use of aprepitant during chemotherapy conditioning. Patients who received aprepitant experienced markedly improved vomiting control.

\section{Clinical Question 10}

What is the optimal treatment to prevent nausea and vomiting for patients receiving multiday chemotherapy?

Recommendation 10. It is suggested that antiemetics appropriate for the emetogenic risk class of the chemotherapy be administered for each day of the chemotherapy and for 2 days after, if appropriate. There is no change from the original guideline.

The Update Committee suggests, based on limited data, that patients receiving 5 -day cisplatin regimens be treated with a $5-\mathrm{HT}_{3}$ antagonist in combination with dexamethasone and aprepitant.

Literature update and analysis 10 . One trial of patients receiving 5-day cisplatin evaluated incorporation of metopimazine with tropisetron. ${ }^{27}$ Findings suggested improved nausea and vomiting.

Noninferiority of the new granisetron transdermal system compared with the oral formulation was validated in a trial of patients who received multiday chemotherapy. ${ }^{28}$ The patch is indicated for use in patients receiving high- or moderate-risk chemotherapy.

\section{Clinical Question 11}

What is the optimal antiemetic regimen for patients who experience nausea and vomiting secondary to cancer therapy despite optimal prophylaxis?

Recommendation 11. Language from the 2006 guideline was reformatted for clarity. Clinicians should re-evaluate emetic risk, disease status, concurrent illnesses, and medications; ascertain that the best regimen is being administered for the emetic risk; consider adding lorazepam or alprazolam to the regimen; and consider adding olanzapine to the regimen or substituting high-dose intravenous metoclopramide for the $5-\mathrm{HT}_{3}$ antagonist or adding a dopamine antagonist to the regimen.

Literature update and analysis 11 . No new evidence was identified.

\section{Clinical Question 12}

What treatment options are available for patients who experience anticipatory nausea and vomiting?

Recommendation 12. Use of the most active antiemetic regimens appropriate for the chemotherapy being administered to prevent acute or delayed emesis is suggested. Such regimens should be used with initial chemotherapy, rather than assessing the patient's emetic response with less effective treatment. If anticipatory emesis 


\begin{tabular}{|ll|}
\hline \multicolumn{2}{|c|}{ Table 4. Emetic Risk by Site of Radiation Therapy } \\
\hline Emetic Risk & Site of Radiation Therapy \\
\hline High & Total-body irradiation \\
& Total nodal irradiation \\
Moderate & Upper abdomen \\
& Upper body irradiation \\
Low & Half-body irradiation \\
& Cranium \\
& Craniospinal \\
& Head and neck \\
& Lower thorax region \\
Minimal & Pelvis \\
& Extremities \\
\hline Data adapted. ${ }^{29}$ & Breast \\
\hline
\end{tabular}

occurs, behavioral therapy with systematic desensitization is effective and suggested. No change since the original guideline.

Literature update and analysis 12. No new evidence was identified.

\section{RADIATION-INDUCED NAUSEA AND VOMITING}

An updated risk stratification table according to site of radiation treatment is provided in Table $4 .^{29}$ Dosing schedules according to risk are listed in Table 5.

\section{Clinical Question 13}

What is the optimal prophylaxis for nausea and vomiting caused by high emetic risk radiation therapy?
Recommendation 13. On the basis of extrapolation from indirect evidence, the Update Committee recommends that all patients should receive a $5-\mathrm{HT}_{3}$ antagonist before each fraction and for at least 24 hours after completion of radiotherapy. Patients should also receive a 5-day course of dexamethasone during fractions 1 to 5 .

Literature update and analysis 13. No new evidence was identified; the modification was based on evidence from the moderaterisk category. ${ }^{30}$

\section{Clinical Question 14}

What is the optimal prophylaxis for nausea and vomiting caused by moderate emetic risk radiation therapy?

Recommendation 14. The Update Committee recommends that patients receive a $5-\mathrm{HT}_{3}$ antagonist before each fraction for the entire course of radiotherapy. Patients may be offered a short course of dexamethasone during fractions 1 to 5 .

Literature update and analysis 14. A new trial that evaluated the efficacy of adding 5 days of dexamethasone during radiation to the upper abdomen was identified. ${ }^{30}$ The addition of dexamethasone provided superior vomiting protection and lower average nausea, both secondary end points.

\section{Clinical Question 15}

What is the optimal treatment to manage nausea and vomiting associated with low emetic risk radiation therapy?

Recommendation 15. The Update Committee recommends a $5-\mathrm{HT}_{3}$ antagonist alone as either prophylaxis or rescue. For patients

\begin{tabular}{|c|c|c|}
\hline Risk Category & Dose & Schedule \\
\hline \multicolumn{3}{|l|}{ High emetic risk } \\
\hline \multicolumn{2}{|l|}{ 5- $\mathrm{HT}_{3}$ antagonist } & $\begin{array}{l}5-\mathrm{HT}_{3} \text { antagonist before each fraction throughout XRT; continue for } \\
\text { at least } 24 \text { hours after completion of XRT }\end{array}$ \\
\hline Granisetron* & \multicolumn{2}{|l|}{$2 \mathrm{mg}$ oral; $1 \mathrm{mg}$ or $0.01 \mathrm{mg} / \mathrm{kg}$ IV } \\
\hline Ondansetron* & \multicolumn{2}{|l|}{$8 \mathrm{mg}$ oral twice daily; $8 \mathrm{mg}$ or $0.15 \mathrm{mg} / \mathrm{kg}$ IV } \\
\hline Palonosetront & \multicolumn{2}{|l|}{0.50 mg oral; 0.25 mg IV } \\
\hline Dolasetron & \multicolumn{2}{|l|}{$100 \mathrm{mg}$ oral only } \\
\hline Tropisetron & \multicolumn{2}{|l|}{$5 \mathrm{mg}$ oral or IV } \\
\hline \multicolumn{3}{|l|}{ Corticosteroid } \\
\hline Dexamethasone & $4 \mathrm{mg}$ oral or IV & During fractions $1-5$ \\
\hline \multicolumn{3}{|l|}{ Moderate emetic risk } \\
\hline 5- $\mathrm{HT}_{3}$ antagonist & $\begin{array}{l}\text { Any of the above listed agents are acceptable; } \\
\text { note preferred optionst }\end{array}$ & $5-\mathrm{HT}_{3}$ antagonist before each fraction throughout XRT \\
\hline \multicolumn{3}{|l|}{ Corticosteroid } \\
\hline Dexamethasone & 4 mg IV or oral & During fractions 1-5 \\
\hline \multicolumn{3}{|l|}{ Low emetic risk } \\
\hline 5- $\mathrm{HT}_{3}$ antagonist & $\begin{array}{l}\text { Any of the above listed agents are acceptable; } \\
\text { note preferred options }\end{array}$ & $\begin{array}{l}\text { 5- } \mathrm{HT}_{3} \text { either as rescue or prophylaxis; if rescue is used, then } \\
\text { prophylactic therapy should be given until the end of XRT }\end{array}$ \\
\hline \multicolumn{3}{|l|}{ Minimal emetic risk } \\
\hline 5- $\mathrm{HT}_{3}$ antagonist & $\begin{array}{l}\text { Any of the above listed agents are acceptable; } \\
\text { note preferred options }\end{array}$ & $\begin{array}{l}\text { Patients should be offered either class as rescue therapy; if rescue } \\
\text { is used, then prophylactic therapy should be given until the end } \\
\text { of XRT }\end{array}$ \\
\hline \multicolumn{3}{|l|}{$\begin{array}{l}\text { Dopamine receptor } \\
\text { antagonist }\end{array}$} \\
\hline Metoclopramide & \multicolumn{2}{|l|}{20 mg oral } \\
\hline Prochlorperazine & \multicolumn{2}{|l|}{10 oral or IV } \\
\hline \multicolumn{3}{|c|}{$\begin{array}{l}\text { Abbreviations: } 5-\mathrm{HT}_{3}, 5 \text {-hydroxytryptamine-3; IV, intravenous; XRT, radiation therapy. } \\
\text { *Preferred agents. } \\
\text { †No data are currently available on the appropriate dosing frequency with palonosetron in this setting. The Update Committee suggests that dosing every second } \\
\text { or third day may be appropriate for this agent. }\end{array}$} \\
\hline
\end{tabular}


who experience RINV while receiving rescue therapy only, prophylactic treatment should continue until radiotherapy is complete.

Literature update and analysis 15 . The recommendation was modified to include rescue therapy.

\section{Clinical Question 16}

What is the optimal treatment to manage nausea and vomiting associated with minimal emetic risk radiation therapy?

Recommendation 16. Patients should receive rescue therapy with either a dopamine receptor antagonist or a $5-\mathrm{HT}_{3}$ antagonist. Prophylactic antiemetics should continue throughout radiation treatment if a patient experiences RINV while receiving rescue therapy.

Literature update and analysis 16. No new evidence was identified.

\section{Clinical Question 17}

What is the optimal treatment to manage nausea and vomiting during concurrent radiation and chemotherapy?

Recommendation 17. Patients should receive antiemetic prophylaxis according to the emetogenicity of chemotherapy, unless the emetic risk with the planned radiotherapy is higher. There is no change from the original guideline.

Literature update and analysis 17. No new evidence was identified.

\section{DRUG FORMULATIONS AND AGENT DOSING}

Since the last update, an orally disintegrating ondansetron tablet became available. ${ }^{31}$ The orally disintegrating form is equivalent with respect to both emesis and nausea control. This is an acceptable alternative to the standard tablet.

Two other antiemetic agents received regulatory approval. As discussed, the granisetron transdermal patch is an option for patients who receive high-risk, multiday chemotherapy. The Update Committee suggests that this agent can also be considered for highor moderate-risk radiation.

Palonosetron is now available orally. ${ }^{32}$ A noninferiority trial documented similarity between the oral and intravenous formulations and validated the dose for the agents when taken orally. ${ }^{33}$

\section{PATIENT AND CLINICIAN COMMUNICATION}

The purpose of this section is to address aspects of patient-provider communication that are relevant to decision making regarding selection of antiemetic therapy. Clinicians are encouraged to provide patients with a prescription for a rescue antiemetic therapy before the patient leaves on the first day of treatment.

Data suggest that physicians frequently underestimate rates of nausea and vomiting secondary to radiation therapy and chemotherapy. ${ }^{34}$ To ensure optimal symptom management, clinicians should assess symptoms throughout therapy. Patient response to antiemetic treatment may change over time, requiring ongoing assessments and modification to antiemetic strategies, as warranted.

Checklists can facilitate collection of direct patient reporting of symptom presence and severity. For example, the National Cancer Institute is developing a Patient-Reported Outcomes version of its Common Terminology Criteria for Adverse Events, which includes two items to assess nausea. ${ }^{35}$ These items are as follows: "In the last 7 days, how OFTEN did you have NAUSEA?” (Never/Rarely/Occasionally/Frequently/Al-

\begin{tabular}{|c|c|c|}
\hline Agent & $\begin{array}{c}\text { Price per Dose } \\
\text { (USD) }\end{array}$ & $\begin{array}{l}\text { Total Cost per } \\
\text { Treatment Cycle } \\
\text { (USD)* }\end{array}$ \\
\hline \multicolumn{3}{|l|}{$\mathrm{NK}_{1}$ antagonists } \\
\hline Aprepitant, 125 mg oral & 150.45 & \multirow{2}{*}{343.03} \\
\hline Aprepitant, 80 mg oral & 96.29 & \\
\hline Fosaprepitant, 150 mg IV & 262.65 & 262.65 \\
\hline \multicolumn{3}{|l|}{$5-\mathrm{HT}_{3}$ antagonists } \\
\hline Granisetron, 2 mg oral & 0.68 & 0.68 \\
\hline Granisetron, 1 mg IV & 17.92 & 17.92 \\
\hline Ondansetron, 8 mg oral & 1.04 & 2.08 \\
\hline Ondansetron, 8 mg IV & 1.19 & 2.38 \\
\hline Palonosetron, 0.25 mg IV & 188.70 & 188.70 \\
\hline Dolasetron, 100 mg oral & 65.21 & 65.21 \\
\hline Ramosetron & Pricing not available & Pricing not available \\
\hline \multicolumn{3}{|c|}{$\begin{array}{l}\text { NOTE. Drug prices were estimated from a third-party payer perspective, based on } \\
\text { reimbursement rates from the Centers for Medicare and Medicaid Services as of the } \\
\text { first quarter of 2011, computed at the manufacturer's average sales price plus } 6 \% \text {. } \\
\text { Other treatment-related direct and indirect costs or discounts were not considered. } \\
\text { Actual treatment costs and reimbursement vary considerably across regions, payers, } \\
\text { institutions, and practices, as well as over time, and the reader should consult current } \\
\text { local cost information specific to his or her specific context. } \\
\text { Abbreviations: } 5-\mathrm{HT}_{3}, 5 \text {-hydroxytryptamine-3; IV, intravenous; NK } 1 \text {, neuro- } \\
\text { kinin 1; USD, US dollars. } \\
{ }^{*} \text { Treatment cycle assumed for single-day agents. }\end{array}$} \\
\hline
\end{tabular}

most constantly) and "In the last 7 days, what was the SEVERITY of your NAUSEA at its WORST?” (None/Mild/Moderate/Severe/Very severe).

Clinicians and patients are also encouraged to discuss cost of treatment (Table 6) to assess whether cost is prohibitive, a hardship to patients, or may impact treatment compliance.

\section{HEALTH DISPARITIES}

ASCO clinical practice guidelines represent evidence-based expert recommendations on best practices to provide the highest level of cancer care. However, it is important to note that many patients have limited access to medical care. Racial and ethnic disparities in health care contribute significantly to this problem in the United States. Racial/ethnic minority patients with cancer suffer disproportionately from comorbidities, experience more substantial obstacles to receiving care, are more likely to be uninsured or underinsured, and are at greater risk of receiving care of poor quality compared with other Americans. ${ }^{36-39}$ Other patients lack access to care because of geography and, specifically, distance from appropriate treatment facilities. Other factors associated with disparities include advanced age, low educational attainment, and low socioeconomic status. Awareness of these disparities should be considered. Health care providers should strive to consider the factors faced by vulnerable populations to ensure that all patients receive the highest level of cancer care.

\section{FUTURE DIRECTIONS}

For most patients, antiemetic regimens prevent emesis and lessen nausea while patients are undergoing cancer therapy. However, some patients continue to report nausea. ${ }^{40}$ Identification of new approachesto decrease nausea is required. Limited research on nausea and vomiting control in special populations is available, particularly pediatric patients. Similarly, few randomized controlled trials have investigated the role of antiemetics 
in patients undergoing radiation therapy. Research to improve symptom control in these patients is necessary.

The Update Committee recommends that studies that include nausea as an outcome include patient-reported measures of nausea, consistent with recommendations of the US Food and Drug Administration. ${ }^{41}$ Standardized approaches to assess nausea should be used across trials, which will allow for improved ability to compare regimens and trial data.

\section{ADDITIONAL RESOURCES}

The full guideline, comprehensive literature discussion, complete methodology, full reference list, evidence tables, and clinical tools and resources can be found at http://www.asco.org/guidelines/ antiemetics. Patient information is available there as well as at http://www.cancer.net.

\section{AUTHORS' DISCLOSURES OF POTENTIAL CONFLICTS} OF INTEREST

Although all authors completed the disclosure declaration, the following author(s) indicated a financial or other interest that is relevant to the subject matter under consideration in this article. Certain relationships marked with a "U" are those for which no compensation was received; those relationships marked with a "C" were compensated. For a detailed description of the disclosure categories, or for more information about ASCO's conflict of interest policy, please refer to the Author Disclosure Declaration and the Disclosures of Potential Conflicts of Interest section in Information for Contributors.

Employment or Leadership Position: None Consultant or Advisory Role: Paul Hesketh, GlaxoSmithKline (C), Helsinn (C), Merck (C); Mark Kris, sanofi-aventis (C), GlaxoSmithKline (C); Petra C. Feyer, GlaxoSmithKline (C), Merck (C) Stock Ownership: None Honoraria: Rebecca Clark-Snow, Merck; Petra C. Feyer, GlaxoSmithKline, Merck, Roche Research Funding: None Expert Testimony: None Other Remuneration: None

\section{AUTHOR CONTRIBUTIONS}

Administrative support: Ann Alexis Prestrud, Paul J. Hesketh,

Mark R. Somerfield

Manuscript writing: All authors

Final approval of manuscript: All authors

\section{REFERENCES}

1. Gralla RJ, Osoba D, Kris MG, et al: Recommendations for the use of antiemetics: Evidencebased, clinical practice guidelines-American Society of Clinical Oncology. J Clin Oncol 17:2971-2994, 1999

2. Kris MG, Hesketh PJ, Somerfield MR, et al: American Society of Clinical Oncology guideline for antiemetics in oncology: Update 2006. J Clin Oncol 24:2932-2947, 2006

3. Grunberg SM, Chua DT, Maru A, et al: Phase III randomized double-blind study of single-dose fosaprepitant for prevention of cisplatin-induced nausea and vomiting. J Clin Oncol 28:641s, 2010 (suppl; abstr 9021)

4. Herrington JD, Jaskiewicz AD, Song J: Randomized, placebo-controlled, pilot study evaluating aprepitant single dose plus palonosetron and dexamethasone for the prevention of acute and delayed chemotherapy-induced nausea and vomiting. Cancer 112:2080-2087, 2008

5. Hoshi E, Takahashi T, Takagi M, et al: Aprepitant prevents chemotherapy-induced nausea and vomiting in Japanese cancer patients receiving highdoes cisplatin: A multicenter randomized, doubleblind, placebo-controlled study. 20th Anniversary International MASCC/ISOO Symposium, St Gallen, Switzerland, June 27-30, 2007 (abstr P-20)

6. Navari R, Gray S, Kerr A: Olanzapine versus aprepitant for the prevention of chemotherapyinduced nausea and vomiting (CINV): A randomized trial. 2010 MASCC/ISOO Symposium, Vancouver, British Columbia, Canada, June 24-26, 2010 (abstr 02-010)

7. Yeo W, Mo FK, Suen JJ, et al: A randomized study of aprepitant, ondansetron and dexamethasone for chemotherapy-induced nausea and vomiting in Chinese breast cancer patients receiving moderately emetogenic chemotherapy. Breast Cancer Res Treat 113:529-535, 2009

8. Grunberg S, Chua D, Maru A, et al: Single-dose fosaprepitant for the prevention of chemotherapy-induced nausea and vomiting associated with cisplatin therapy: Randomized, double-blind study protocol-EASE. J Clin Oncol 29:1495-1501, 2011

9. Hesketh PJ, Kris MG, Grunberg SM, et al: Proposal for classifying the acute emetogenicity of cancer chemotherapy. J Clin Oncol 15:103-109, 1997

10. Billio A, Morello E, Clarke MJ: Serotonin receptor antagonists for highly emetogenic chemotherapy in adults. Cochrane Database Syst Rev 1:CD006272, 2010

11. Saito M, Aogi K, Sekine I, et al: Palonosetron plus dexamethasone versus granisetron plus dexamethasone for prevention of nausea and vomiting during chemotherapy: A double-blind, double-dummy, randomised, comparative phase III trial. Lancet Oncol 10:115-124, 2009

12. Jordan K, Hinke A, Grothey A, et al: A metaanalysis comparing the efficacy of four 5-HT3-receptor antagonists for acute chemotherapy-induced emesis. Support Care Cancer 15:1023-1033, 2007

13. Ho CL, Su WC, Hsieh RK, et al: A randomized, double-blind, parallel, comparative study to evaluate the efficacy and safety of ramosetron plus dexamethasone injection for the prevention of acute chemotherapy-induced nausea and vomiting. Jpn $\mathrm{J}$ Clin Oncol 40:294-301, 2010

14. Aapro MS, Grunberg SM, Manikhas GM, et al: A phase III, double-blind, randomized trial of palonosetron compared with ondansetron in preventing chemotherapy-induced nausea and vomiting following highly emetogenic chemotherapy. Ann Oncol 17:1441-1449, 2006

15. Yu Z, Liu W, Wang $L$, et al: The efficacy and safety of palonosetron compared with granisetron in preventing highly emetogenic chemotherapy-induced vomiting in the Chinese cancer patients: A phase II, multicenter, randomized, double-blind, parallel, comparative clinical trial. Support Care Cancer 17:99-102, 2009

16. Aapro M, Fabi A, Nole F, et al: Double-blind, randomised, controlled study of the efficacy and tolerability of palonosetron plus dexamethasone for 1 day with or without dexamethasone on days 2 and 3 in the prevention of nausea and vomiting induced by moderately emetogenic chemotherapy. Ann Oncol 21:1083-1088, 2010
17. Rapoport BL, Jordan K, Boice JA, et al: Aprepitant for the prevention of chemotherapy-induced nausea and vomiting associated with a broad range of moderately emetogenic chemotherapies and tumor types: A randomized, double-blind study. Support Care Cancer 18:423-431, 2010

18. Celio L, Frustaci S, Denaro A, et al: Palonosetron in combination with 1-day versus 3-day dexamethasone for prevention of nausea and vomiting following moderately emetogenic chemotherapy: A randomized, multicenter, phase III trial. Support Care Cancer 19:1217-1225, 2011

19. Tan L, Liu J, Liu X, et al: Clinical research of olanzapine for prevention of chemotherapy-induced nausea and vomiting. J Exp Clin Cancer Res 28:131, 2009

20. Ryan JL, Heckler C, Dakhil SR, et al: Ginger for chemotherapy-related nausea in cancer patients: $\mathrm{A}$ URCC CCOP randomized, double-blind, placebocontrolled clinical trial of 644 cancer patients. J Clin Oncol 27:485s, 2009 (suppl; abstr 9511)

21. Ezzo JM, Richardson MA, Vickers $A$, et al: Acupuncture-point stimulation for chemotherapyinduced nausea or vomiting. Cochrane Database Syst Rev 2:CD002285, 2006

22. Phillips RS, Gopaul S: Antiemetic medication for prevention and treatment of chemotherapy induced nausea and vomiting in childhood. Cochrane Database Syst Rev 9:CD007786, 2010

23. Gore L, Chawla S, Petrilli $A$, et al: Aprepitant in adolescent patients for prevention of chemotherapyinduced nausea and vomiting: A randomized, doubleblind, placebo-controlled study of efficacy and tolerability. Pediatr Blood Cancer 52:242-247, 2009

24. Sepúlveda-Vildósola AC, Betanzos-Cabrera $Y$, Lastiri GG, et al: Palonosetron hydrochloride is an effective and safe option to prevent chemotherapyinduced nausea and vomiting in children. Arch Med Res 39:601-606, 2008

25. Giralt S, Mangan K, Maziarz R, et al: Palonosetron (PALO) for prevention of chemotherapy-induced nausea and vomiting (CINV) in patients receiving high-dose melphalan prior to stem cell transplant (SCT). J Clin Oncol 26:531s, 2008 (suppl; abstr 9617) 
26. Stiff $P$, Fox-Geiman $M$, Kiley $K$, et al: Aprepitant vs. placebo plus oral ondansetron and dexamethasone for the prevention of nausea and vomiting associated with highly emetogenic preparative regimens prior to hematopoietic stem cell transplantation: A prospective, randomized doubleblind phase III trial. Blood 114:2267, 2009 (abstr)

27. Herrstedt J, Sigsgaard TC, Nielsen HA, et al: Randomized, double-blind trial comparing the antiemetic effect of tropisetron plus metopimazine with tropisetron plus placebo in patients receiving multiple cycles of multiple-day cisplatin-based chemotherapy. Support Care Cancer 15:417-426, 2007

28. Boccia RV, Gordan LN, Clark G, et al: Efficacy and tolerability of transdermal granisetron for the control of chemotherapy-induced nausea and vomiting associated with moderately and highly emetogenic multi-day chemotherapy: A randomized, double-blind, phase III study. Support Care Cancer lepub ahead of print on September 12, 2010]

29. Gralla RJ, Roila F, Tonato M, et al: MASCC/ ESMO antiemetic guideline 2010. http://data.member clicks.com/site/mascc/MASCC_Guidelines_English_ 2010.pdf

30. Wong RK, Paul N, Ding $K$, et al: 5Hydroxytryptamine-3 receptor antagonist with or without short-course dexamethasone in the prophylaxis of radiation induced emesis: A placebo- controlled randomized trial of the National Cancer Institute of Canada Clinical Trials Group (SC19). J Clin Oncol 24:3458-3464, 2006

31. Pectasides D, Dafni U, Aravantinos G, et al: A randomized trial to compare the efficacy and safety of antiemetic treatment with ondansetron and ondansetron zydis in patients with breast cancer treated with high-dose epirubicin. Anticancer Res 27:4411-4417, 2007

32. US Food and Drug Administration: Drug information on oral palonosetron. http://www.accessdata .fda.gov/scripts/cder/drugsatfda/index.cfm?fuseaction= Search.DrugDetails

33. Grunberg S, Voisin D, Zufferli $M$, et al: Oral palonosetron is as effective as intravenous palonosetron: A phase III dose ranging trial in patients receiving moderately emetogenic chemotherapy. Presented at the 14th European Conference of Clinical Oncology, Barcelona, Spain, September 23-27, 2007

34. Basch $\mathrm{E}$ : The missing voice of patients in drug-safety reporting. N Engl J Med 362:865-869, 2010

35. National Cancer Institute: Patient-Reported Outcomes version of the CTCAE (PRO-CTCAE). https://wiki.nci.nih.gov/display/PROCTCAE/PatientReported + Outcomes + version + of + the + CTCAE + \%28PRO-CTCAE \%29
36. US Cancer Statistics Working Group: United States cancer statistics: 1999-2002 Incidence and mortality Web-based report. http://apps.nccd.cdc .gov/uscs/

37. American Cancer Society: Cancer Facts and Figures for African Americans 2005-2006. Atlanta, GA, American Cancer Society, 2005

38. Mead H, Cartwright-Smith $L$, Jones $K$, et al: Racial and Ethnic Disparities in U.S. Health Care: A Chartbook. New York, NY, The Commonwealth Fund, 2008

39. Ries LAG, Eisner MP, Kossary $C L$, et al: SEER Cancer Statistics Review 1973-1997. Bethesda, MD, National Cancer Institute, 2000

40. Hickok JT, Roscoe JA, Morrow GR, et al: Nausea and emesis remain significant problems of chemotherapy despite prophylaxis with 5-hydroxytryptamine-3 antiemetics: A University of Rochester James P. Wilmot Cancer Center Community Clinical Oncology Program Study of 360 cancer patients treated in the community. Cancer 97:2880-2886, 2003

41. US Food and Drug Administration: Guidance for industry: Patient-reported outcome measures-Use in medical product development to support labeling claims. http://www.fda.gov/ downloads/Drugs/GuidanceComplianceRegulatory Information/Guidances/UCM193282.pdf 